\title{
Microbiological quality of Portuguese yogurts
}

\author{
C Nogueira, H Albano, P Gibbs and P Teixeira \\ Escola Superior de Biotecnologia, R Dr António Bernardino de Almeida, 4200 Porto, Portugal
}

The microbiological quality of four brands of natural yogurts and two probiotic yogurts available in the Portuguese market, was evaluated during the shelf-life period. Although the specific flora decreased during storage it was always within the range of recommended values. No coliforms and an insignificant number of fungi were detected.

Keywords: yogurt; Lactobacillus bulgaricus; Streptococcus thermophilus; Lactobacillus acidophilus; Bifidobacterium spp

\section{Introduction}

Yogurt may be defined as the end product of a controlled fermentation of high solids whole milk with a symbiotic mixture of Streptococcus salivarius subsp thermophilus (termed S. thermophilus hereafter) and Lactobacillus delbrueckii subsp bulgaricus (termed L. bulgaricus hereafter). L. bulgaricus degrades casein supplying peptides and aminoacids to the weakly proteolytic streptococci. Growing more rapidly at the beginning, $S$. thermophilus lowers the redox potential and slightly acidifies the milk. These conditions are stimulatory for $L$. bulgaricus that acidifies the milk even more [14]. Together, the two species ferment almost all the lactose to lactic acid and flavour the yogurt with diacetyl ( $S$. thermophilus) and acetaldehyde ( $L$. bulgaricus).

Unlike Lactobacillus acidophilus and bifidobacteria, most strains of $L$. bulgaricus and $S$. thermophilus are highly sensitive to gastric acid and bile salts, and show poor survival during transit through the gastro-intestinal tract to the colon [7]. A number of health benefits have been claimed for $L$. acidophilus and bifidobacteria due to the ability of these organisms to establish themselves amongst the colonic microflora and they are increasingly being incorporated into dairy products. It seems reasonable to assume that the beneficial effects of these probiotic bacteria can be expected only when viable cells are ingested.

In the past some studies indicated that the hydrogen peroxide produced by yogurt cultures might be detrimental to the viability of added cells of L. acidophilus [2]. In addition, the viability of Lactobacillus and Bifidobacterium species diminishes markedly during refrigerated storage [18].

The main objective of this study was to evaluate and compare the microbiological quality of different yogurts available in the Portuguese market in terms of the viability of the natural flora and the presence of contaminants during the shelf-life period; $\mathrm{pH}$ values were also determined as another quality indicator.

Correspondence: P Teixeira, Escola Superior de Biotecnologia, R Dr António Bernardino de Almeida, 4200 Porto, Portugal

\section{Materials and methods}

Four different brands of natural solid (set) yogurts (A, B, $\mathrm{C}, \mathrm{D})$ and two different brands of natural probiotic yogurts containing L. acidophilus (E) and Bifidobacterium spp (F) were analyzed. Two different lots of each brand were analyzed. Yogurts were obtained in the market 1 week after production and transported to the laboratory at refrigeration temperature. Products were maintained at $4^{\circ} \mathrm{C}$ and individual pots of the same batch code analyzed until the sell-bydate (approximately 4 weeks after production).

\section{pH analyses}

The $\mathrm{pH}$ values of the yogurts were measured at $20^{\circ} \mathrm{C}$ using a Crison $2002 \mathrm{pH}$ meter after calibrating with fresh $\mathrm{pH} 4.0$ and 7.0 standard buffers.

\section{Microbiological analyses}

Two 10-g samples of yogurt were diluted with $90 \mathrm{ml}$ of sterile $0.1 \% \mathrm{w} / \mathrm{v}$ peptone water (Lab M, Bury, UK). After uniform mixing, subsequent serial decimal dilutions were prepared in $9 \mathrm{ml}$ of sterile $0.1 \% \mathrm{w} / \mathrm{v}$ peptone water. Duplicate plates of each set of dilutions were prepared. These procedures were performed in duplicate for each of two batches of yogurt.

\section{Streptococcus salivarius subsp thermophilus}

Enumeration was performed according to NP1864 [9] on M17 agar (Lab M) using the pour plate technique. Plates were incubated aerobically at $37^{\circ} \mathrm{C}$ for $48 \mathrm{~h}$.

\section{Lactobacillus delbrueckii subsp bulgaricus}

Enumeration was performed according to NP1864 [9] on acidified (pH 5.4 with $100 \%$ glacial acetic acid) MRS agar (Lab M) using the pour plate technique. Plates were incubated under microaerophilic conditions (produced by burning a candle to extinction in a closed container) at $37^{\circ} \mathrm{C}$ for $72 \mathrm{~h}$.

\section{Bifidobacterium spp}

Enumeration was performed on de Man, Rogosa, Sharp (MRS) agar with the addition of $4.476 \% \mathrm{v} / \mathrm{v}$ NNPL solution using the pour plate technique [6]. Plates were incubated 
under anaerobic conditions at $37^{\circ} \mathrm{C}$ for $72 \mathrm{~h}$. NNPL solution contains per $100 \mathrm{ml}$ : $0.030 \mathrm{~g}$ nalidixic acid (Sigma, St Louis, MO, USA); 0.20 g neomycin (Sigma); $0.25 \mathrm{~g}$ paromomycin (Sigma); $6.00 \mathrm{~g} \mathrm{LiCl} \mathrm{(Merck,} \mathrm{Frankfurt,}$ Germany).

\section{Lactobacillus acidophilus}

Enumeration was performed on MRS agar in which glucose was substituted by an equal amount of maltose [1], using the pour plate technique. Plates were incubated under microaerophilic conditions at $37^{\circ} \mathrm{C}$ for $72 \mathrm{~h}$.

\section{Yeasts and moulds}

Enumeration was performed according to NP 1934 [10] on rose bengal agar with chloramphenicol ( $\mathrm{Lab} \mathrm{M}$ ) using the spread plate technique. Plates were incubated under aerobic conditions at $23^{\circ} \mathrm{C}$ for 5 days.

\section{Coliforms}

The presence of coliforms was examined according to NP 1935 [11] using lactose broth and brilliant green broth as growth media. Turbidity, colour changes and production of gas were all presumptive evidence of the presence of coliform organisms.

\section{Results and discussion}

Higher $\mathrm{pH}$ values were observed in probiotic yogurts than in the traditional yogurts (Tables $1-3$ ). Brand $C$ yogurt was an exception since it was the only product which had $\mathrm{pH}$ values lower than 4.0 (Table 1). No significant variations in $\mathrm{pH}$ values were observed during storage at $4^{\circ} \mathrm{C}$.

According to Radke-Mitchell and Sandine [14], the balance between lactobacilli and streptococci is critical for yogurt flavour development. When streptococci predominate, a mild acid flavour with a fuller aroma from diacetyl and acetaldehyde results, whereas a predominance of lactobacilli gives a sharply acidic flavour and a good yogurt

Table 1 Survival of L. bulgaricus and S. thermophilus and $\mathrm{pH}$ evolution in natural solid yogurts during storage at $4^{\circ} \mathrm{C}$

\begin{tabular}{|c|c|c|c|c|}
\hline Brand & $\begin{array}{c}\text { Time } \\
\text { (weeks) }\end{array}$ & $\begin{array}{l}\text { L. bulgaricus } \\
\left(\mathrm{CFU} \mathrm{g}^{-1}\right. \\
\left.\left(\times 10^{7}\right)\right)\end{array}$ & $\begin{array}{c}S . \\
\text { thermophilus } \\
\left(\mathrm{CFU} \mathrm{g}^{-1}\right. \\
\left.\left(\times 10^{7}\right)\right)\end{array}$ & $\mathrm{pH}$ \\
\hline A & 1 & 6.3 & 100 & 4.2 \\
\hline A & 2 & 1.0 & 20 & 4.2 \\
\hline A & 3 & 4.0 & 251 & 4.2 \\
\hline A & 4 & 4.0 & 100 & 4.2 \\
\hline B & 1 & 0.8 & 400 & 4.1 \\
\hline B & 2 & 1.0 & 1259 & 4.1 \\
\hline B & 3 & 2.0 & 1259 & 4.1 \\
\hline B & 4 & 1.0 & 1000 & 4.0 \\
\hline $\mathrm{C}$ & 1 & 1000 & 316 & 3.8 \\
\hline $\mathrm{C}$ & 2 & 398 & 316 & 3.8 \\
\hline $\mathrm{C}$ & 3 & 1000 & 794 & 3.8 \\
\hline $\mathrm{C}$ & 4 & 40 & 100 & 3.7 \\
\hline D & 1 & 16 & 794 & 4.2 \\
\hline D & 2 & 10 & 200 & 4.2 \\
\hline D & 3 & 4.0 & 126 & 4.2 \\
\hline D & 4 & 0.8 & 158 & 4.1 \\
\hline
\end{tabular}

Table 2 Survival of L. bulgaricus, S. thermophilus and L. acidophilus and $\mathrm{pH}$ evolution in natural probiotic yogurts (brand $\mathrm{E}$ ) during storage at $4{ }^{\circ} \mathrm{C}$

\begin{tabular}{lcccc}
\hline $\begin{array}{l}\text { Time } \\
\text { (weeks) }\end{array}$ & $\begin{array}{c}\text { L. bulgaricus } \\
\left(\mathrm{CFU} \mathrm{g}^{-1}\right. \\
\left.\left(\times 10^{7}\right)\right)\end{array}$ & $\begin{array}{c}\text { S. } \\
\text { thermophilus } \\
\left(\mathrm{CFU} \mathrm{g}^{-1}\right. \\
\left.\left(\times 10^{7}\right)\right)\end{array}$ & $\begin{array}{c}\text { L. acidophilus } \\
(\mathrm{CFU} \mathrm{g})^{-1} \\
\left.\left(\times 10^{7}\right)\right)\end{array}$ & $\mathrm{pH}$ \\
\hline 1 & & 6309 & 40 & 4.4 \\
2 & 158 & 3981 & 16 & 4.4 \\
3 & 63 & 1995 & 32 & 4.4 \\
4 & 20 & 631 & 25 & 4.3 \\
\hline
\end{tabular}

aroma. Pette and Lolkema [12] reported that for proper flavour development the initial ratio of $S$. thermophilus to L. bulgaricus should be in the range of $1: 1$ to $3: 1$. It is generally agreed that this ratio should be approximately $1: 1[15]$.

As may be seen in Table 1, with the exception of product C, S. thermophilus was always present in higher numbers than L. bulgaricus. In product C, there was a predominance of L. bulgaricus, confirmed by the low $\mathrm{pH}$ of the product.

Puhan et al [13] indicated that viability of $S$. thermophilus and L. bulgaricus in yogurt was dependent upon $\mathrm{pH}$. Numbers of $S$. thermophilus increased in yogurts with an initial $\mathrm{pH}$ greater than 4 until the $\mathrm{pH}$ decreased below 4, and the numbers then diminished rapidly. Numbers of $L$. bulgaricus either remained constant or increased for the first 10-20 days with an initial $\mathrm{pH}$ greater than 4 and then decreased [13]. These results were not confirmed by our results in which an increase, maintenance or decrease in the numbers of $S$. thermophilus and L. bulgaricus does not seem to be related to $\mathrm{pH}$ (Table 1). Numbers of L. bulgaricus decreased faster than did those of $S$. thermophilus (Table 1) but both were consistently greater than $10^{7} \mathrm{CFU}$ $\mathrm{g}^{-1}$ which is the recommended value by the Portuguese norms [9] and the International Dairy Federation [3]. The yogurt organism survival curves were quite different for the different brands tested. According to Medina and Jordano [8], this is possibly due to manufacturing practices and the strains of starter cultures utilised by the different manufacturers.

L. acidophilus, L. bulgaricus and S. thermophilus in product F (Table 2) and Bifidobacteria spp and S. thermophilus in product $\mathrm{G}$ (Table 3 ), all showed a decline in the number of survivors during storage. L. bulgaricus, the main factor

Table 3 Survival of L. bulgaricus, S. thermophilus and Bifidobacterium spp and $\mathrm{pH}$ evolution in natural probiotic yogurts (brand $\mathrm{F}$ ) during storage at $4{ }^{\circ} \mathrm{C}$

\begin{tabular}{lcccc}
\hline $\begin{array}{l}\text { Time } \\
(\text { weeks })\end{array}$ & $\begin{array}{c}\text { L. bulgaricus } \\
\left(\mathrm{CFU} \mathrm{g}^{-1}\right. \\
\left.\left(\times 10^{7}\right)\right)\end{array}$ & $\begin{array}{c}\text { S. thermophilus } \\
\left(\mathrm{CFU} \mathrm{g}^{-1}\left(\times 10^{7}\right)\right)\end{array}$ & $\begin{array}{c}\text { Bifidobacterium } \\
\text { spp }\left(\mathrm{CFU} \mathrm{g}^{-1}\right. \\
\left.\left(\times 10^{7}\right)\right)\end{array}$ & $\mathrm{pH}$ \\
\hline 1 & $\mathrm{ND}$ & 1585 & 63 & 4.3 \\
2 & $\mathrm{ND}$ & 1585 & 16 & 4.3 \\
3 & $\mathrm{ND}$ & 1259 & 0.16 & 4.3 \\
4 & $\mathrm{ND}$ & 943 & 0.25 & 4.3 \\
\hline
\end{tabular}

ND, Not detected. 
responsible for L. acidophilus and Bifidobacterium spp, mortality [17], was not present in product G. The decline was, however, much more rapid for bifidobacteria compared to L. acidophilus. Suggested minimum levels of probiotic bacteria in yogurt are $10^{6} \mathrm{CFU} \mathrm{g}^{-1}$ [5]. It was observed that both products contained probiotic organisms in greater numbers than those suggested. The correlation between high numbers of $S$. thermophilus and a sufficient level of Bifidobacterium spp (Table 3), confirmed that $S$. thermophilus could be beneficial for Bifidobacterium spp as an oxygen scavenger [4]. As expected, due to the low $\mathrm{pH}$ and presence of living lactic acid bacteria in the yogurts, no coliforms were detected.

Certain yeasts play an important role in the spoilage of fermented products. Since milk is pasteurised before yogurt production, the presence of yeasts in yogurt is caused by recontamination processes during manufacture [16], and can be a problem in fruit-containing yogurts. The maximum number of moulds found was $6.8 \times 10^{2} \mathrm{CFU} \mathrm{g} \mathrm{g}^{-1}$ (Brand A) and the number of yeasts was always $<1.0 \times 10^{2} \mathrm{CFU} \mathrm{g}^{-1}$, which according to the Portuguese norms, is an acceptable value.

\section{References}

1 Hull RR and AV Roberts. 1984. Differential enumeration of Lactobacillus acidophilus in yogurt. Aust J Dairy Technol 3: 160-164.

2 Hull RR, AV Roberts and JJ Mayes. 1984. Survival of Lactobacillus acidophilus in yogurt. Aust J Dairy Technol 39: 164-166.

3 IDF. 1992. General standard of identity for fermented milks. IDF Standard 163. International Dairy Federation, Brussels.

4 Ishibashi $\mathrm{N}$ and S Shimamura. 1993. Bifidobacteria: research and development in Japan. Food Technol 47: 126-134.
5 Kurman JA and JL Rasic. 1991. The health potential of products containing bifidobacteria. In: Therapeutic Properties of Fermented Milks (Robinson RK, ed), pp 117-158, Elsevier Applied Food Science Series, London.

6 Laroia S and JH Martin. 1991. Methods for enumerating and propagating bifidobacteria. Cult Dairy Prod J 26: 32-33.

7 Marteau P, M Minekus, R Havenaar and JHJ Huis In't Veld. 1997. Survival of lactic acid bacteria in a dynamic model of the stomach and small intestine: validation and the effects of bile. J Dairy Sci 80: 1031-1037.

8 Medina LM and R Jordano. 1994. Survival of constitutive microflora in commercially fermented milk containing bifidobacteria during refrigerated storage. J Food Prot 56: 731-733.

9 Norma Portuguesa NP1864. 1987. Iogurte. Contagem da flora específica. Processo de referência. Instituto Português da Qualidade.

10 Norma Portuguesa NP1934. 1986. Leites e Produtos Lácteos. Contagem de bolores e leveduras. Instituto Português da Qualidade.

11 Norma Portuguesa NP1935. 1986. Leites e Produtos Lácteos. Pesquisa de bactérias coliformes. Instituto Português da Qualidade.

12 Pette JW and H Lolkema. 1950. Yogurt III Zuurvorming en aromavorming in yogurt. Neth Milk Dairy J 5: 261-273.

13 Puhan Z, O Flueler and M Banhegyi. 1973. Mikrobiologischer Zustand, sowi-Memge umd Konfiguration der Milchsáure des industriell hergestellen Johurts in der Schweizerisch. Schweizerisch Milchwirtschaftliche Forschung 2: 37-45.

14 Radke-Mitchell L and WE Sandine. 1984. Associative growth and differential enumeration of Streptococcus thermophilus and Lactobacillus bulgaricus: a review. J Food Prot 47: 245-248.

15 Rasic JL and JA Kurman. 1978. Yogurt. Scientific Grounds, Technology, Manufacture and Preparations. Technical Dairy Publishing House, Denmark.

16 Rohm H, F Lechner and M Lehner. 1990. Microflora of Austrian Natural-Set Yogurt. J Food Prot 53: 478-480.

17 Rybka S and K Kailasapathy. 1995. The survival of culture bacteria in fresh and freeze-dried AB yogurts. Aust J Dairy Technol 50: 51-57.

18 Shah NP, WEV Lankaputhra, ML Britz and WSA Kyle. 1995. Survival of Lactobacillus acidophilus and Bifidobacterium bifidum in commercial yogurt during refrigerated storage. Int Dairy J 5: 515-521. 